electronic work, there was also displayed in another room the success so far achieved in attempting to answer the simply stated question: How can one ensure free movement of mercury drops in sealed glass tubes such as are used in rocker contacts on electrical relays, etc., so as to avoid faulty makeand-break ?

Studies on the gas permeability of thermocouple sheaths, performance specifications for electric ovens, fluid flow of liquids and gases, and the use of pneumatic (air-jet) gauges for observations on the curvature and thickness of lenses, provided further evidence of the wide scope of the Association's activities.

There were many indications of the flexibility of the broad divisional organization of the laboratories, supported by excellent drawing-office and workshop facilities. One learned that all divisions contribute to the information and liaison services, partly by providing background for the Information Department in dealing with technical inquiries, and partly by visits to member firms to study works procedures, to discuss immediate practical problems, and to seek advice about investigations being carried out by the Association. It is noteworthy that heads of divisions and senior staff generally are expected to spend some 20 per cent of their time in such visiting.

It would seem that those member firms which enter into active membership of the British Scientific Instrument Research Association in all its aspects may benefit exceedingly.

\section{ALLEGHENY OBSERVATORY, UNIVERSITY OF PITTSBURG}

A

SHORT account of the origin and development of the Allegheny Observatory of the University of Pittsburg (pp. 12; from the University) has been compiled by Theodora M. Lauterbach, which makes very interesting reading. The appearance of Donati's Comet in $\mathbf{1 8 5 9}$ aroused a new interest in astronomy, and a group of Pittsburg business men soon organized the 'Allegheny 'Telescope Association' and made plans for the purchase of a large telescope. This 13-in. refractor was made by Fitz, of New York, and was installed in the new building complete with dome, on a hill in the old eity of Allegheny which later became part of Pittsburg. In 1867 the Association presented the telescope and building to the Western University of Pennsylvania - now the University of Pittsburgand in the same year Samuel Pierpont Langley went to Pittsburg as professor of astronomy and director of Allegheny Observatory. Under him, and through financial assistance from William Thaw, a Pittsburg industrial leader, the equipment in the Observatory was greatly improved.

John A. Brashear, a former mill-worker, who had shown a wonderful aptitude for making lenses, and who was encouraged in this work by Langley, played a prominent part in the development of the Observatory. When James F. Keeler, who succeeded Langley in 1891, resigned in 1898 to take up the directorship of Lick Observatory, Brashear became temporary acting director until the following year, when F. L. O. Wadsworth took charge. During the latter's period as director, most of his time was devoted to supervising the construction of the buildings and instruments for the new Observatory, and with Brashear's assistance their efforts were rewarded by the laying of the foundation stone in October 1900. In 1912 the new Allegheny Observatory was dedicated and presented to the University of Pittsburg, and Dr. Frank Schlesinger was appointed director.

The account describes the excellent work of Schlesinger and the succeeding directors-Curtis, Jordan and others-and, as the author says at the end of this interesting brochure, "The Observatory's location serves well for uninterrupted research, and it is through research that Allegheny Observatory has helped to make the University of Pittsburg known throughout the world". The publication contains thirteen photographs of directors, instruments, and portions of the Observatory buildings.

\section{NUFFIELD FOUNDATION}

\section{ANNUAL REPORT}

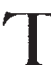
HE seventh report of the Nuffield Foundation covers the year ending March 31, 1952*, and is the third in the current period of the present programme, during which allocations totalling $£ 620,311$ have been made for fundamental research in the United Kingdom; of this, $£ 189,261$ is for biological and $£ 189,950$ for sociological studies, and $£ 110,000$ is reserved for research overseas in the Commonwealth, of which $\mathfrak{4 0 , 1 9 0}$ has been allocated in Australia, $£ 12,712$ in New Zealand and $£ 18,500$ in South Africa. The cost of existing schemes to the end of the quinquennium is estimated at the $£ 498,892$ already set aside, while $£ 112,921$ has been devoted during the current quinquennium to the continuance and extension of projects in medicine, science and the care of old people begun in the first programme. From the Oliver Bird Fund, $£ 114,000$ has been used or reserved for research in rheumatism.

By thus reserving in advance from current income $£ 1,504,849$ of $£ 1,596,042$ allocated in grants for the quinquennium, the Foundation seeks to assure itself of future freedom in the event of any fluctuations either in income or objectives and opportunities. For the advancement of research in the United Kingdom the Foundation has been concerned chiefly to stimulate studies in biology and sociology and, outside these two fields, any other research of real importance or promise which lacks the funds required for its full development. For financing projects of this latter type, the Foundation has set aside a sum which is termed the 'free fund', the use of which is essentially unplanned, and from this fund grants totalling $£ 241,000$ have been allocated during the past year. The greater part of this is to meet the Foundation's commitment to share with the Department of Scientific and Industrial Research the cost of the steerable radio telescope at the Jodrell Bank Experimental Station of the University of Manchester. This grant will avert the postponement of the project because sufficient public funds could not be made available. Grants from the same fund have been made to the University of Cambridge towards the cost of sinking and lining a borehole at or near the geophysical laboratories for experiments and measurements deep into the earth's crust, and towards the construction, during the next five years, of a new and improved high-speed electronic calculating

* Nuffield Foundation. Report for the Year ending 31 March 1952 Pp. 162. (London: Nuffield Foundation, 1952.) 
machine. A three-year grant has also been made to Prof. J. Rotblat, of the Physics Department, St. Bartholomew's Hospital Medical College, to enable him to retain two technicians specially trained in the photographic emulsion technique he uses in his study of nuclear energy states, and a grant of $£ 14,000$ has been made to the Royal Anthropological Institute for the establishment for five years of the Nuffield blood group research and reference centre, which came into operation on January $1,1952$.

Griants totalling $\mathfrak{f 9 5 , 4 9 2}$ promised during the year for biological studies include those to the University of Cambridge for theoretical investigations at the Chemical Laboratory on molecular structure with the view of their application to biological problems and the study of animal behaviour, particularly studies of imprinting, habituation, insight and homing orientation at the Madingley ornithological field station; to the University of Leeds for studies on the molecular structure of collagen and infra-red techniques in the Department of Biomolecular Structure; and to the Lister Institute of Preventive Medicine to enable investigations on the isolation and characterization of antigens to be resumed and for the continuance of the work on co-enzyme $A$ and related substances. Grants have been made to the University of London to increase the biological balance of the team working in the Wheatstone Physical Laboratory at King's College, under Prof. $J$. T. Randall, on the structure and function of nucleic acids in cells and the structure and fibrogenesis of the collagen of connective tissues ; for the work on the embryonic brain at the Department of Anatomy and Embryology, at University College; and for the work on proliferation and morphology in the adult in the same Department, in association with the Department of Physiology; while grants have also been made to the Department of Clinical Pathology of University College Hospital Medical School for work on the red cells of human blood and to the Department of Morbid Anatomy for work on the responses to injury, and subsequent repair and regeneration, in liver and other tissues; the Obstetric Unit of the same School has received a grant for assisting the application of the sensitive electronic recording apparatus required for the further development of the work on the normal pattern of uterine contractions in child-birth and the effects of drugs on the contractions.

A grant of up to $£ 4,000$ has been made to the University of Manchester to enable Dr. H. C. B. Slack to investigate the metabolism of the extracellular substances of the body at the Rheumatism Research Centre. The University of Oxford has accepted grants for the continuance of work at the Physical Chemistry Laboratory on the mechanism by which resistance to various drugs and antibodies of a bacterial population is increased; for a graduate assistant to Dr. W. Holmes, of the Department of Zoology and Comparative Anatomy, to extend, along histological, histochemical and biochemical lines, his work on the adrenal cortex in lungfish; and for building up in the same Department a research unit in animal behaviour. A grant has also been made to enable the Strangeways Research Laboratory, Cambridge, to provide a worker trained in tissue culture and histology to collaborate with the Sir William Dunn Department of Biochemistry, University of Cambridge, in work on the effect of insulin and other hormones on the rudimentary long bones and animal tissues grown in tissue-culture.
The Foundation's grants for sociological studies are aimed primarily at aiding non-economic subjects, but two recent grants have been made for applied economic research : one of $£ 6,500$ to the Department of Applied Economics, University of Cambridge, is to collect and construct the social accounts of Cambridgeshire; the other, of $£ 11,500$, is to the Institute of Statistics, University of Oxford, for a national sample-survey of personal savings, to be carried out in two succeeding years. Both these projects have strong social implications and will make use of sample-interview techniques, thus contributing to the further development of this essential tool of social research. Grants totalling $£ 3,200$ have been made to the Department of Social Anthropology, University of Edinburgh, to finance work under Dr. Kenneth Little on the organization of Colonial students in London, their educational activities, etc., the social organization of coloured people in Manchester, and, in West Africa, on the complex social and economic factors which give rise to emigration and direct it to Britain. A grant has been made of $£ 3,500$ for the creation, for five years, of a research fellowship at Bedford College, University of London, to be held by Mrs. Barbara Wootton to review the whole field of social research. A grant of $£ 4,000$ has gone to the Department of Town Planning, University College, London, for a two-year study of the contribution of the social sciences to the principles and techniques of town and country planning and a survey of the processes of planning.

From the Oliver Bird Fund a further grant of

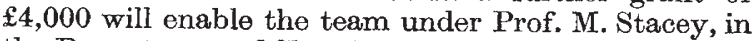
the Department of Chemistry, University of Birmingham, to continue for two or three years its studies of the organic chemical structure and enzymatic behaviour of the tissue components and joint fluids. The grant of $£ 1,100$ for the examination of the steroids of ox-bile, the original source of cortisone, under Prof. F. S. Spring at the School of Chemistry, Royal Technical College, Glasgow, has been renewed for a further two years. Renewed grants totalling $£ 7,041$, for the two years ending 1954 , have been made to the Rheumatic Unit, Northern General Hospital, Edinburgh, for continued clinical work with cortisone, studies of cortisone as an adjuvant to the treatment of anæmia in rheumatoid arthritis and other fundamental work. Renewed grants have also been made to the Orthopædic and Accident Department, London Hospital, to enable Mr. A. Law to continue his studies of surgical treatment in rheumatic disease of the hip, spine and knee, to the Postgraduate Medical School, University of London, for the retrospective follow-up of patients, and to the South-west and Oxford Regional Research Unit, Bath, for completing therapeutic trials of X-ray therapy in osteoarthritis, rheumatoid arthritis, and spondylitis, and of intra-articular injections in osteoarthritis.

New grants for research overseas within the Commonwealth include those to the Waite Agricultural Research Institute, University of Adelaide, to enable Dr. H. L. Penman, of Rothamsted Experimental Station, to visit Australia in connexion with work on evaporation; for Dr. D. F. Thomson, of the Department of Anthropology, University of Melbourne, to visit social anthropologists in the United Kingdom and later to revisit Arnhem Land; to the Department of Chemistry, University of Western Australia, for equipment and infra-red spectroscopical research on Australian 
natural products; to the University of Otago, for studies in the Department of Botany of morphology and chromosome numbers in Ranunculus and trans plantation experiments and population analyses, at the Portobello Marine Biological Station, of the physiological mechanisms of animal behaviour and the interpretation of their structure in these terms, and, in the Department of Zoology, of the processes of bird-life. Grants have also been made to the University of Pretoria for work at the Plant Physiological Research Institute on nitrogen assimilation and metabolism in leguminous plants; to the Research Department of Ichthyology, Rhodes University, for research on freshwater fishes of southern Africa; to the Transvaal Museum, Pretoria, for completing the excavations at Swartkrans; and to the Bernard Price Institute of Geophysical Research, University of the Witwatersrand, for the establishment of a Nuffield Geochemical Unit.

For the second year's selection, applications for biological scholarships and bursaries have been stronger in number and quality, and out of thirty eligible applicants, two were awarded scholarships and one bursary; two sociological scholarships and one bursary were also awarded to the twenty-two applicants under that scheme. The Foundation has reviewed the scheme of travelling scholarships for farmers of the United Kingdom, and reports from the National Farmers' Union suggest that the objects of the scheme are being achieved : ten awards, among sixty-four applicants, were made in 1951. Two travelling fellowships for Home Civil Servants, one in the administrative and one in the professional grade, were made in the year. Only six applications were made for dental fellowships, and three awards were made. Three medical fellowships were awarded among sixteen applicants.

Among new grants for miscellaneous projects may be mentioned one of $£ 3,000$ for the compilation of an archive of the Smuts papers and $£ 15,000$ towards the inter-congress meetings of the Association of Universities of the British Commonwealth ; $£ 650$ to the British Cornmittee for Flame Radiation Research to enable a British physicist to work at the Stockholm Technical College's water-cooled plant with heatabsorbing walls; to the British Sociological Association for its first three years, and to Dr. H. Lehmann, of the Department of Pathology, St. Bartholomew's Hospital, for investigations of the blood of south Indian aboriginal tribes, which seem to show that the sickle-cell trait connects the Veddians with Africa although their Rhesus blood-groups point to connexion with Australia. A grant of $£ 1,580$ to the University of Reading will enable Miss M. D. Vernon, of the Department of Psychology, to direct a three-year study of visual methods in teaching. New grants in continuation of past programmes include a final grant of $£ 4,500$ to the Joint Committee of the Royal College of Obstetricians and Gynæcologists, the Population Investigation Committee and the Institute of Child Health, for completing and publishing a report on the study of growth, health and environment of a sample of children from birth to the first year of school life; of $£ 18,000$ to the University of Cambridge for the work at the Psychological Laboratory on the problems of ageing, and of $£ 600$ for three years to Mr. F. Le Gros Clark for investigations on the social influences that determine retirement, and the employment of ageing persons, and on the capacity of industry to absorb the labour of ageing persons.

\section{SEISMIC REFRACTION EXPERIMENTS IN THE PACIFIC}

\author{
By DR. T. F. GASKELL and J. C. SWALLOW \\ H.M.S. Challenger
}

THIS communication summarizes the results of seismic refraction experiments carried out in H.M.S. Challenger in the Pacific during the period October 1950-April 1952. Sixteen stations have been occupied in this area ; their positions, and those of the Atlantic stations already described ${ }^{1}$, are shown on the accompanying chart. The observed structures fit into five groups, described below.

(1) Deep ocean types. Four stations showed a sea bed consisting of a comparatively thin layer of sediment overlying material with a high velocity for compressional sound waves $(20,500 \mathrm{ft}$. $/ \mathrm{sec}$.). The velocity of sound in the sediment layer was not observed at these stations, but from other measurements is taken to be between 6,000 and $8,000 \mathrm{ft}$./sec. (Table $A$ ).

Reverse shots at stations 8,10 and 11 showed that there was no appreciable slope under the hydrophones. There was no reverse shot at station 17 , but the results from successive shots suggest that there may be a small slope, which would give a true velocity of $21,000 \mathrm{ft} . / \mathrm{sec}$. , and a few hundred feet increase in sediment thickness.

(2) Deep ocean near islands. Two stations, one near the Hawaiian islands, the other twenty miles from Funafuti, showed a thin layer of sediment, followed by several thousand feet of material with a sound-velocity of $11,000-15,000 \mathrm{ft}$./ sec. overlying the high-velocity layer (Table $B$ ).

At station 9 , a reverse shot confirmed the 13,500 ft./sec. velocity, but at neither station were reverse points obtained from the high-velocity layer.

Allowing for the remaining possibility of a dip in this layer, the observed velocities are not incompatible with the previous value of $20,500 \mathrm{ft}$. $/ \mathrm{sec}$. Adopting this velocity would change the thickness of covering material by only a few hundred feet.

(3) Western Pacific. Two stations in deep water, south-west of Formosa, showed a lower sound-velocity for the main layer, with about $2,000 \mathrm{ft}$. of sediment cover (Table $C$ ).

The depth of the sea bed was variable; but several reverse shots were made and corrections applied for dip under the hydrophones.

(4) 'Continental' types. The results at stations 6 and 7, off the North American coast, were not checked by reverse shots, and were obtained over an irregular sea bed. However, two distinct layers are indicated at each station, and the velocity of sound in the deeper layer is substantially less than the 20,500 ft./sec. of the deep Pacific stations. Stations 14 and 15 show a velocity of about 17,000 ft./sec., confirmed by reverse shots (Table $D$ ).

At station 15, an increase of velocity with depth in the sediment layer was observed, from about $5,000 \mathrm{ft}$./sec. to $8,300 \mathrm{ft}$./sec., the latter layer probably being consolidated sediment.

(5) Near deep trenches. Stations 13 and 18 were in the deep trench south-west of Guam, at $11 \frac{1}{2} \mathrm{~N}$. $142 \frac{1}{2} \mathrm{E}$. Some indication of a layer with very high velocity $(27,000 \mathrm{ft}$./sec.) was obtained, but the results were rendered uncertain by drift of the hydrophones over a very irregular sea bed, and by the weakness of the ground waves obtained in these great depths 